UDC 621.313

\title{
A ENERGY EFFICIENT ELECTRIC DRIVE OF AIR UNITS
}

KOTSUR I.M. PhD, Associate Professor, Associate Professor of the Department of Electrical Machines, Zaporizhzhia Polytechnic National University, Zaporizhzhia, Ukraine, e-mail: igor.m.kotsur@gmail.com; ORCID: 0000-0001-6394-7849;

HURAZDA A.V. student of the Department of Electrical Machines, Zaporizhzhia Polytechnic National University, Zaporizhzhia, Ukraine, e-mail: artemgurazda@gmail.com; ORCID: 0000-00025853-2339;

DOLIA B.A. $\quad$ student of the Department of Electrical Machines, Zaporizhzhia Polytechnic National University, Zaporizhzhia, Ukraine, e-mail: bgdn.n@mail.com; ORCID: 0000-0002-29809538;

SHESTOV L.E. $\quad$ student of the Department of Electrical Machines, Zaporizhzhia Polytechnic National University, Zaporizhzhia, Ukraine, e-mail: luka84867@gmail.com; ORCID: 0000-0001-72553729

Purpose. Improving the efficiency and energy performance of an asynchronous electric drive for stationary fan's units of the main ventilation line of mines.

Methodology. The research was carried out using the methods of the theory of electrical circuits, mathematical physics, simulation, interpolation and approximation

Findings. The research of electromagnetic and energy processes in the asynchronous electric drive system with pulse control at a fan load, taking into account the variable aerodynamic parameters of the main ventilation line of mines. An electric drive system is able to respond with high accuracy and reliability to changes in the aerodynamic parameters of the main ventilation line of mines has been proven. This will also increase the power factor of the electric drive at a fan load up 0.8 to 0.93 p.u., and the efficiency up $92.5 \%$ to $94.5 \%$, when regulating in the range of the operating slip of the rotor of the drive fan motor $s=0.5 \div s_{\text {rated }}$, which, respectively, is on average up $0,25 \%$ to 40 higher in comparison with systems of an unregulated electric drive. Recommendations has been developed for the design and rational selection of the rated fan capacity for the main ventilation line to advance the best energy efficiency level of the electric drive.

Originality. The research of electro-mechanical, electro-energy power and aerodynamic processes in the dynamic modes of the fan electric drive was carried out. The fan-loaded "induction motor-converter" system has been proven to be self-regulating. It is able to respond with high accuracy and reliability even at low switching frequencies of the power chopper to any changes of the aerodynamic parameters of the main ventilation line of mines.

Practical value. Recommendations has been developed for the design and rational selection of the rated fan capacity for the main ventilation line to advance the best energy efficiency level of the electric drive.

Keywords: converter; fan unit; energy efficiency; pressure; pulse regulating

\section{INTRODUTION}

Ventilation of mines with main ventilation fans (MVF) is the most energy-intensive technological process. Average rated power of fan drives $1000-1600$ $\mathrm{kW}$, and for the most powerful units up to $4000 \mathrm{~kW}$. Therefore, the electricity consumption of the MVF reaches to $30 \%$ of the total consumption at the mine. The MVF park at the mines of the region (481 units) is rundown by more than $77 \%$. At the same time 370 fans worked for two or more standard periods [1]. Almost all mines for MVF use unregulated electric drive systems. A characteristic feature of the mine ventilation line determines the operating mode of the MVF. The mode of operation of the MVF is constantly changing (variable) aerodynamic resistance during the operation of the mine (aerodynamic resistance, which changes during the operation of the mine). This is due to a change in the configuration of the ventilation scheme, the length and cross-sectional area of mine workings, the nature of the surface of their walls, the state of ventilation structures and mine's production, as well as other factors [2]. Only after some time ( 5 - 10 years) the line resistance becomes comparable to its initial calculated (prospective) value. According to the centrally-doubled ventilation scheme, the resistance changes in relation to the calculated one by an average of 4-10 times. For diagonally ventilation scheme - from one and a half to 2.5 times [2]. The mode of operation of the MVF is significantly affected by the depression of natural draft, which changes cyclically throughout the year. The required air consumption by a mine does not always depend on the intensity of emission of harmful gases, the number of ventilated objects, and air leaks in mine's production. Based on the foregoing, it can be concluded that it is advisable to regulate the parameters of MVF. In recent years, the productivity of most of the mines has decreased and the number of operating working mine bottom at relatively successful

(C) Kotsur I.M., Hurazda A.V., Dolia B.A., Shestov L.E., 2021

DOI 10.15588/1607-6761-2021-1-2 
enterprises has decreased. As a result, air demand of mines has decreased, that the efficiency of many units has decreased, which leads to high electricity consumption. In order to increase the efficiency of a significant amount of MVF, a providing the lowest motor speed is possible. his can be done with help the use of energy efficient electric drive control systems.

\section{II.ANALYSIS OF LAST RESEARCHES}

In order to increase the efficiency of a significant amount of MVF, it is possible to applying lower rotor speed of induction motor, with help energy-efficient electric drive control systems, such as frequency converters (FC), inductor-capacitive converters (ICC) and converters according to the asynchronous-valve cascade (AVC) scheme. With these systems it is possible to independently control the speed and torque of the electric motor (asynchronous or synchronous) [3] - [5]. However, the frequency converters and the inductor-capacitive converters has a large rated power, which is commensurate with the power of the VGP motor. In addition, the application of the frequency converters and the inductorcapacitive converters for the high-voltage electric drive MVF is limited in using of the voltage class of the semiconductor elements of the converters.

In [6] - [7] a system of asynchronous electric drive with pulse control is proposed, which combines the positive control characteristics of classical pulse control with the possibility of energy recuperation into the network. In comparison with the inductor-capacitive converters, the asynchronous electric drive with pulse control allows independently saving a AC in the rotor with changing parameters of the induction motor in the subsynchronous range of rotor speed [8]. The asynchronous electric drive with pulse control has proved itself well in electric drives of lifting-and-shifting mechanisms, and can also be effectively used for powerful high-voltage electric drives of fan units, where the use of high-voltage frequency converters leads to a significant increase their cost. The source of current (torque) in the rotor of the asynchronous electric drive with pulse control for controlling fan loads makes it possible, at a given air pressure, to automatically select the operating point of the flow-pressure characteristics of the ventilated object or hydraulic supply object, at a variable air flow rate. The asynchronous electric drive with pulse control improves the energy efficiency of the units and mechanisms in various industries [9].

Therefore, an urgent task is to research the control properties and energy efficiency indicators of an asynchronous electric drive with pulse control with a fan load, which ensures satisfactory electromagnetic compatibility with the network. Thus, the purpose of the work is to increase the efficiency and energy performance of an asynchronous electric drive with pulse control with a fan load.

\section{FORMULATION OF THE WORK PURPOSE}

The purpose of the work is improving the efficiency and energy performance of an asynchronous electric drive for stationary fan's units of the main ventilation line of mines.

\section{EXPOUNDING THE MAIN MATERIAL AND RESULTS ANALYSIS}

In fig. 1 shows the asynchronous electric drive with pulse control system. A feature of this system is the presence of a pulse regulator in the rectified current circuit of the rotor, which performs the function of a pulse DC voltage converter. When the key is opened, the sleepenergy of the rotor is recovered to the network at a constant inversion angle of a low-power inverter. This ensures the minimum consumption of reactive energy from the network and will improve the power factor of the asynchronous electric drive in the full range of rotor speed.

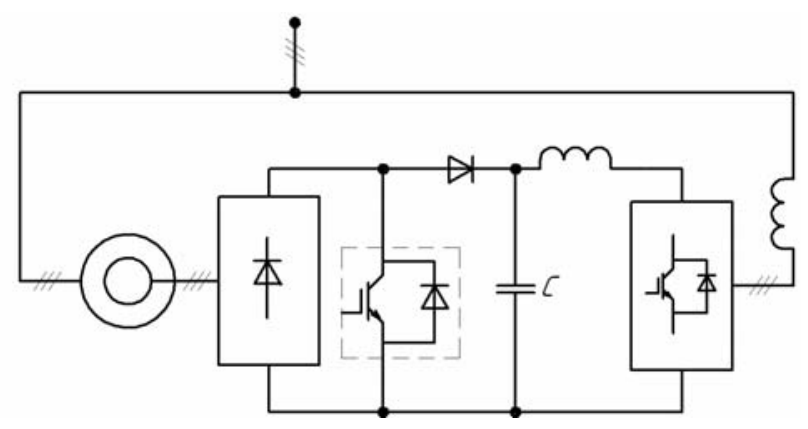

Figure 1. The Asynchronous electric drive with pulse control system

To research the control properties and energy efficiency indicators of an asynchronous electric drive in the structure of Simulink of the MatLAB software, a complex simulation model of electromagnetic and energy processes was developed. It includes: a subsystem of the model of a high-voltage induction motor with a wound rotor, created according to generally accepted assumptions [10] - [12]; the subsystem of the model of the control channel in the rectified current rotor, according to [13]; a mathematical block for calculating energy indicators, according to [13], as well as a subsystem of the aerodynamic model.

The subsystem of the aerodynamic model is described by the following expressions [15]:

$$
\begin{gathered}
M=M_{i}+k \cdot \omega_{r}{ }^{n}, \\
k \cong\left(M_{\text {rated }}-M_{i}\right) / \omega_{\text {rated }}^{n}, \\
M_{\text {rated }}=\frac{H \cdot Q}{\eta \cdot \omega},
\end{gathered}
$$


where $M_{i}$ is the idling toque (the toque of starting the system), Nm; $\omega_{\text {rated }}$ - rated speed of the motor, $\mathrm{rad} / \mathrm{s}$; $\omega_{r}$ - operating speed of the motor, $\mathrm{rad} / \mathrm{s} ; n$ - exponent, a value that depends on the type of unit (for fan load $n=2$ ); $\eta$ - coefficient of efficiency of the fan; $H$ - fan pressure, Pa; $Q$ - volumetric fan air output, $\mathrm{m}^{3} / \mathrm{s}$.

The relationship between the fan air output and the pressure in the main ventilation line can be expressed by following relationship [15]:

$$
H=R \cdot Q^{2},
$$

where $R$ is the resistance of the main ventilation line, $\mathrm{Pa}$ $\mathrm{s}^{2} / \mathrm{m}^{6}$.

The current limitation in the subsystem of the asynchronous model is performed by the control subsystem, i.e. pulse width modulator. It provides independent setting of the pulse duty cycle $\gamma$ and the switching frequency $f_{k}$.

The input parameters of the asynchronous electric drive control subsystem are: rated pressure in the main ventilation line of a coal mine $H_{\text {rated }}$; effective values of pressure $H$ and volumetric fan air output $Q$. The subsystem of the regulation model provides selfregulation for required pressure $H_{\text {rated }}$ by changing the speed of the induction motor $\omega_{r}$; This value is set by the value of the pulse duty cycle $\gamma$ with time sampling $T$ :

$$
\left\{\begin{array}{lll}
\gamma_{i}=\gamma_{i-1}+k_{i}\left(T_{i}\right) & \text { if } & H \leq H_{\text {rated }} \\
\gamma_{i}=\gamma_{i-1}-k_{i}\left(T_{i}\right) & \text { if } & H \succ H_{\text {rated }}
\end{array}\right.
$$

where $k_{i}$ is a discrete value, that characterizes the rate of change $\gamma$ at sampling time $T$.

In fig. 2 shows the simulation results in the form of oscillograms of aerodynamic indicators and control parameters: mine line resistance $R$ (fig. 2, a); the pressure in the mine line $H$ (fig. 2, b); volumetric fan air output $Q$ (fig. 2, c); the toque of the induction motor (fig. 2, d); pulse duty cycle $\gamma$ (fig. 2, e); rotor speed (fig. 2, e), for induction motor type AK-4, $1000 \mathrm{~kW}$ at switching frequency $f_{k}=600 \mathrm{~Hz}$.

On oscillograms showed the period of speed-up of the induction motor $(\mathrm{t}=0 \div 3.5 \mathrm{sec}$. $)$, as well as the quasisteady operation mode of asynchronous electric drive with pulse control system $(\mathrm{t}=3.5 \div 7 \mathrm{sec}$. $)$ with a constant resistance of the mine ventilation line $R=0,083$ $\mathrm{Pa} \cdot \mathrm{s}^{2} / \mathrm{m}^{6}$. At the time $\mathrm{t}=7 \mathrm{sec}$, the simulation of the change the resistance of the mine ventilation line $R$ from $0.083 \mathrm{~Pa} \cdot \mathrm{s}^{2} / \mathrm{m}^{6}$ to $0.053 \mathrm{~Pa} \cdot \mathrm{s}^{2} / \mathrm{m}^{6}$ is performed. At the time 10 sec., the mine ventilation line changing up 0.053 $\mathrm{Pa} \cdot \mathrm{s}^{2} / \mathrm{m}^{6}$ to $0.018 \mathrm{~Pa} \cdot \mathrm{s}^{2} / \mathrm{m}^{6}$, which indicates about inflation in coal production in the mine. As a result of a abrupt decrease in the resistance of the mine ventilation line, the pressure in the main line decreases.

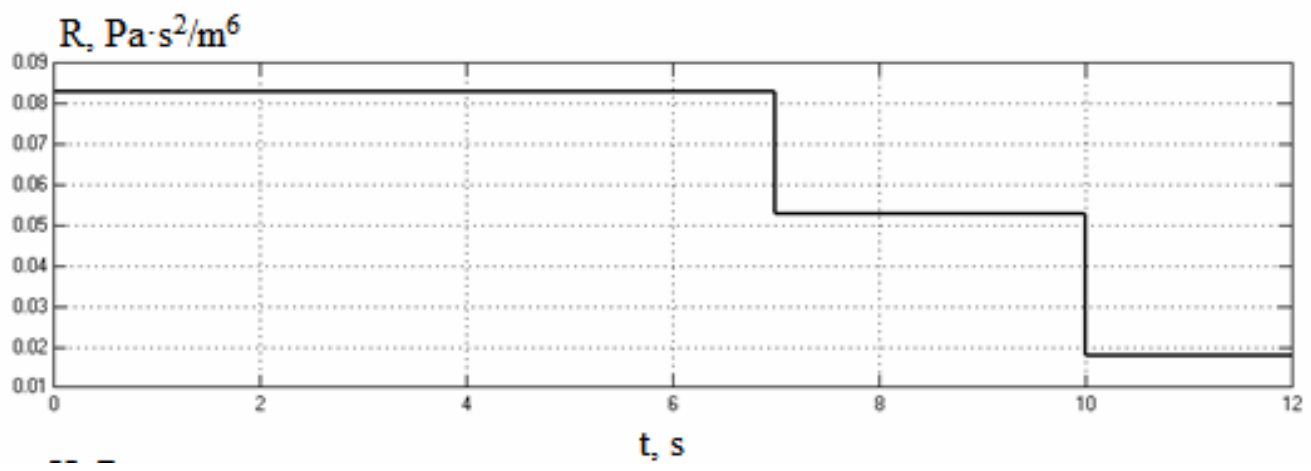

a)

$\mathrm{H}, \mathrm{Pa}$

$\therefore$

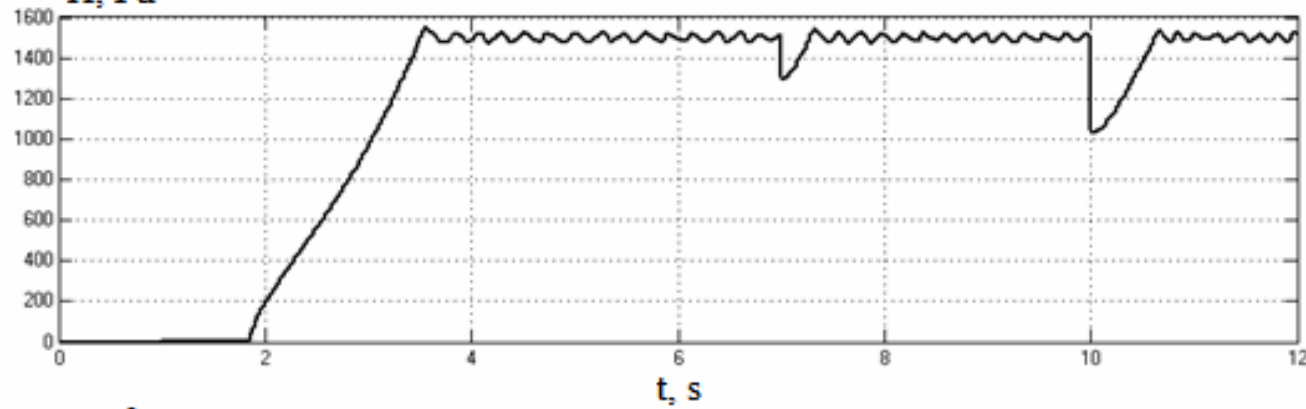

b) 


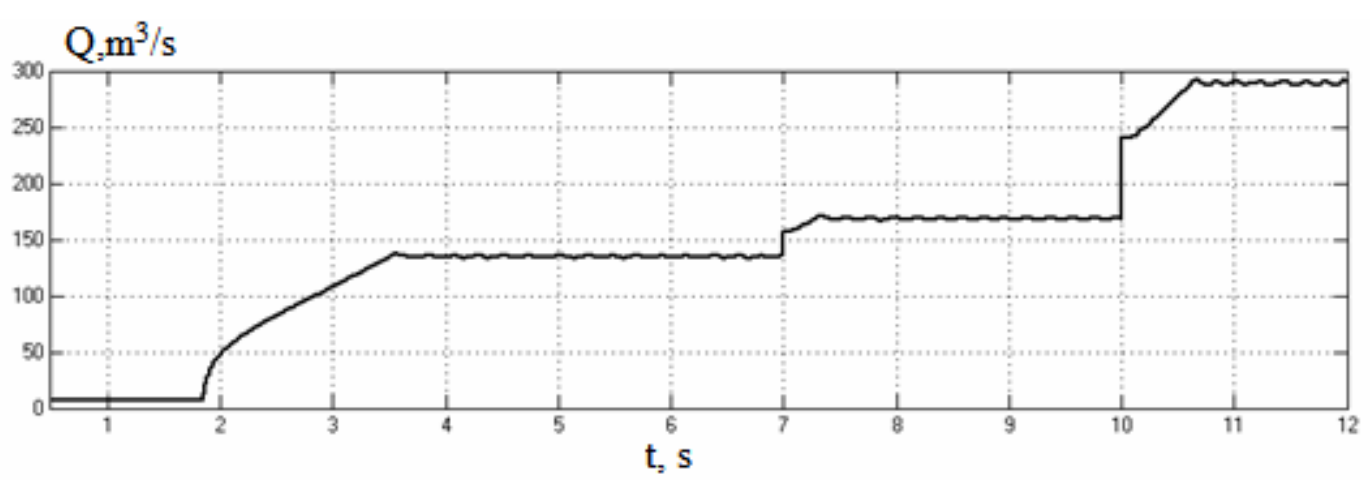

c)

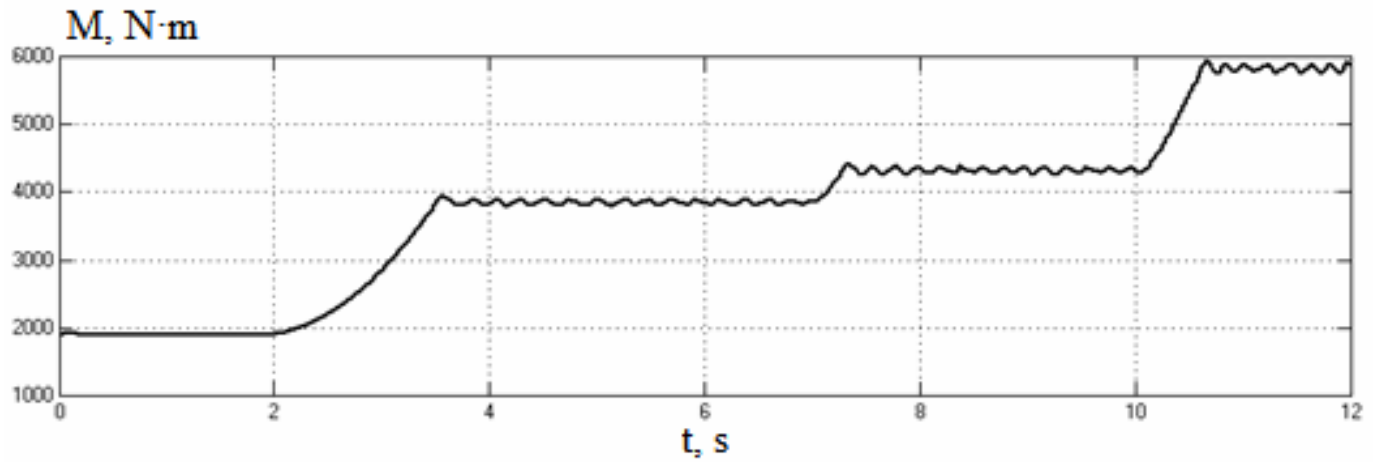

d)

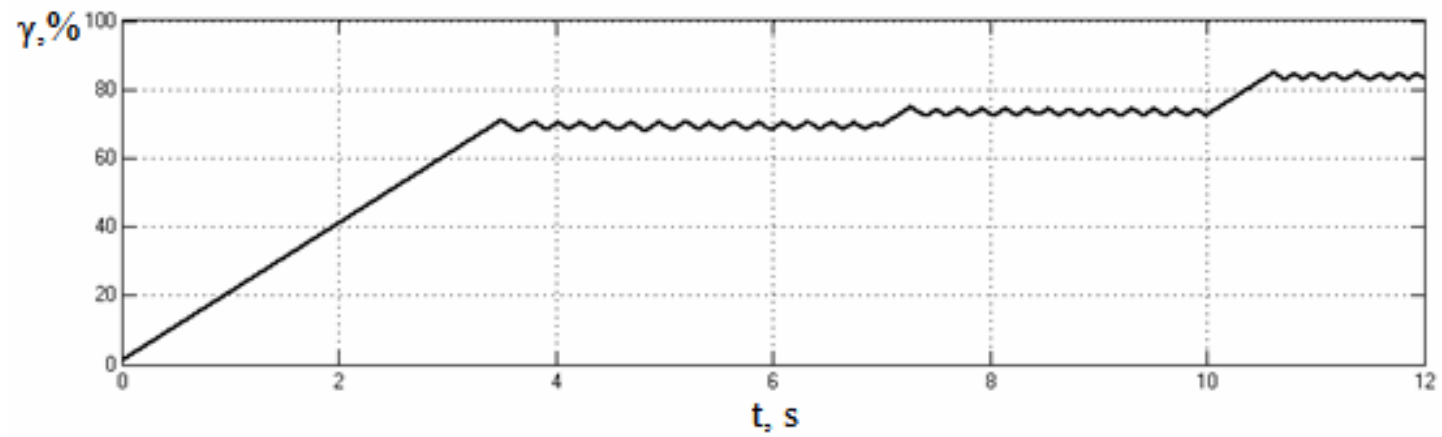

e)

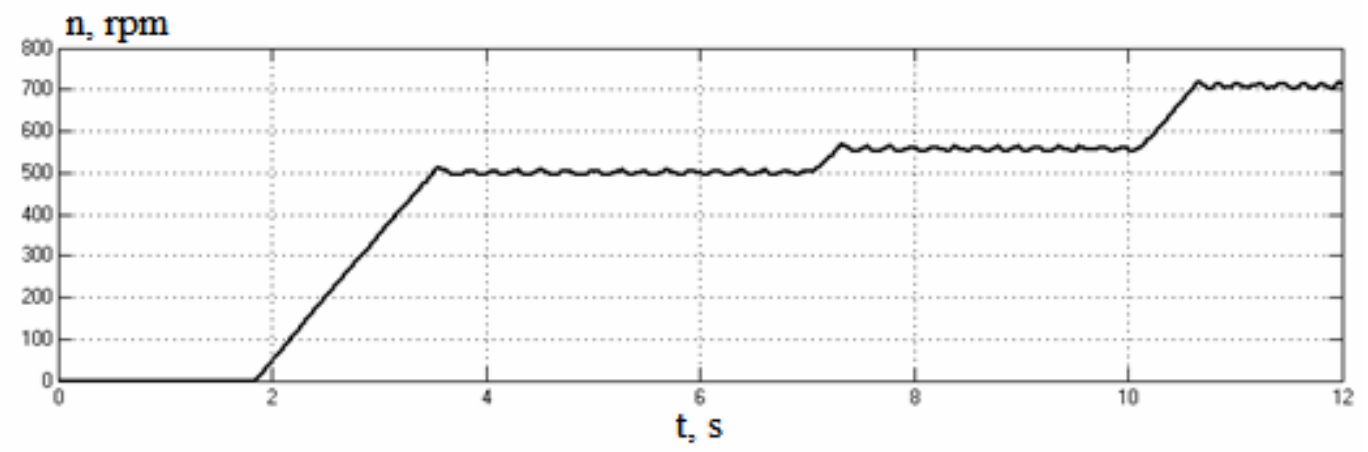

f)

Figure 2. Simulation results in the form of oscillograms of aerodynamic indicators and control parameters of asynchronous electric drive with pulse control system for induction motor type AK-4, $1000 \mathrm{~kW}$

The asynchronous electric drive with pulse control system respond on a change value of the pressure $H$ in the main line by setting a larger value of the pulse duty cycle $\gamma$ according to (5) until the fan pressure $H$ reaches the rated value $H_{\text {rated }}$. 
Thus, an increase of the pressure in the mine line is provided by an increase in the rotor current, therefore, the torque of the induction motor. At the time of self-regulation, with a smooth change in the pulse duty factor $(\gamma)$, the appearance of rush components of AC and the induction motor torque is excluded, ensuring the stable operation of the electric drive system.

In fig. 3 shows the calculated values of the power factors of the induction motor type AK-4 (curves 1, 2, 3 ), as well as the overall power factor of the drive (curves $4,5,6$ ), respectively, for the rated power of the induction motor 630,800 and $1000 \mathrm{~kW}$. It follows from the analysis, that the use of an asynchronous electric drive with pulse control system will allow increase the power factor of the fan units by 0.25 p.u. compared to an unregulated electric drive system due to the operation of the inverter with a constant minimum inversion angle $\beta$. In this case, the inverter power uses a minimum amount of reactive power from the network. A decrease of the power factor with an increasing of the working slip rotor of the induction motor is caused by a decrease of the c power uses of active power from the network. As well as an increasing of higher harmonics of the stator and rotor currents of the induction motor. This is due to the fact, that the value of the harmonic distortion factor of the stator and rotor of the induction motor is inversely proportional to the value of the pulse duty cycle $\gamma[16]-[17]$.

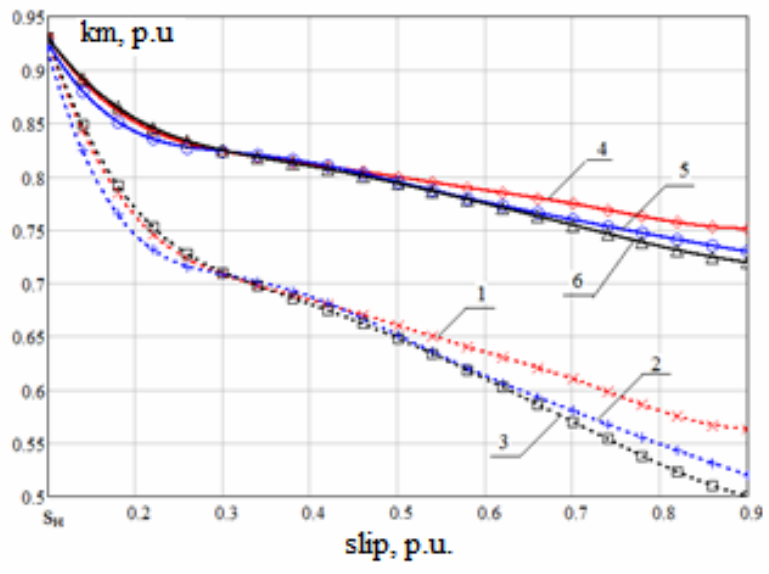

1 -for electric drive system, $630 \mathrm{~kW}$;

2 - for for electric drive system $800 \mathrm{~kW}$;

3 - for for electric drive system $1000 \mathrm{~kW}$;

4 - for induction motor, $630 \mathrm{~kW}$;

5 - for induction motor $800 \mathrm{~kW}$;

6-for induction motor $1000 \mathrm{~kW}$;

Figure 3. Dependences of the power factor of induction motor for type AK-4 and the power factor of asynchronous electric drive with pulse control system on the working slip

The use of asynchronous electric drive with pulse control system for fan units will also allow saving the overall efficiency in the subsynchronous rotor speed range on high level up 92 to $94.5 \%$. (fig. 4).

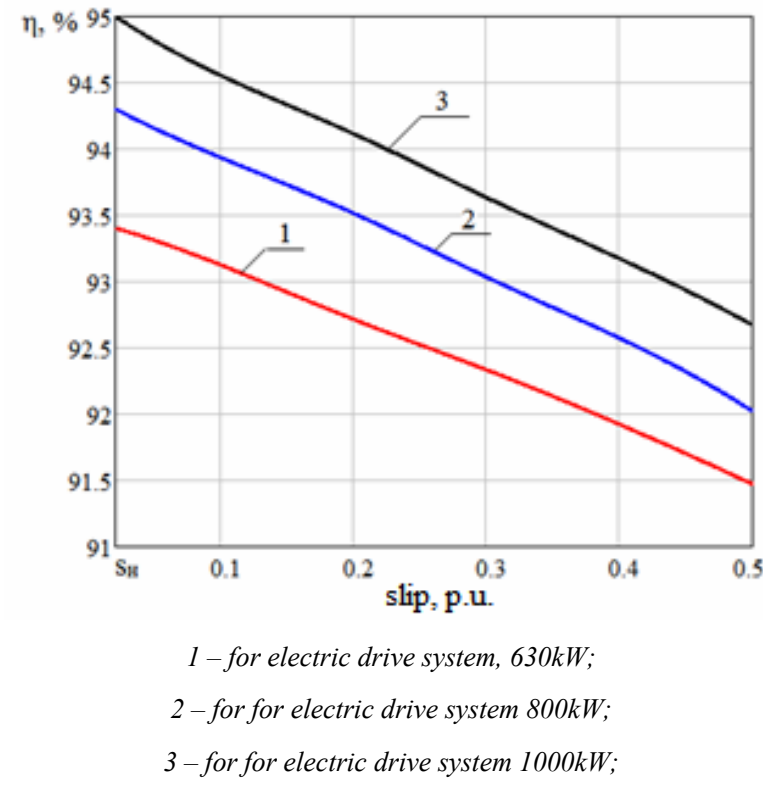

Figure 4. Calculated dependences of the efficiency of the asynchronous electric drive with pulse control system on the value of the induction motor operating slip

According to fig. 3, fig. 4, the optimal level of energy efficiency is ensured in the range of working rotor sleep $s=0.5 \div \mathrm{s}_{\text {rated }}$. Therefore, at designing of the asynchronous electric drive with pulse control system for fan units, it is necessary that the initial and final calculated values of aerodynamic resistance $R$, as well as the required value of the line pressure $H$, be selected in such a way, that the range of operating sleeps of the induction motor equal to $\mathrm{s}=0.5 \div \mathrm{s}_{\text {rated }}$. In addition, the induction motor should be selected with the highest possible rated power and could ensure the operation of the fan in the range of specified operating rotor sleeps of the induction motor.

Thus, the asynchronous electric drive with pulse control system for the fan units of the mine ventilation line allows ensure:

- high level of the energy efficiency;

- self-regulation of aerodynamic parameters;

- to reduce capital costs in the process of upgrading the asynchronous electric drive with pulse control system for fan units.

This will increase their stability and reliability, thus reducing the level of accidents at mines in Ukraine.

\section{V.CONCLUSION}

The research of electromagnetic and energy processes in the asynchronous electric drive system with pulse control at a fan load, taking into account the 
variable aerodynamic parameters of the main ventilation line of mines. A electric drive system is able to respond with high accuracy and reliability to changes in the aerodynamic parameters of the main ventilation line of mines has been proven. This will also increase the power factor of the electric drive at a fan load up 0.8 to 0.93 p.u., and the efficiency up $92.5 \%$ to $94.5 \%$, when regulating in the range of the operating slip of the rotor of the drive fan motor $s=$ $0.5 \div s_{\text {rated }}$, which, respectively, is on average up $0,25 \%$ to 40 higher in comparison with systems of an unregulated electric drive.

Recommendations has been developed for the design and rational selection of the rated fan capacity for the main ventilation line to advance the best energy efficiency level of the electric drive.

\section{REFERENCE}

[1] Mazin, V. A., Olhovskiy O. V., Kostenko V. A. (2008). Reduction of power consumption for ventilation of the mines. Ugol Ukrainyi, 8, 19-21.

[2] Varenik E. A., Omelchenko N. A., Dubinsky A. A., Labeznik R. M. (2010). Energy saving concept for stationary installations in coal mines. Ugol Ukrainyi, 3, 7-20/

[3] Onischenko, G. B. (1967). Wound-rotor slip recovery system. Moscow, Energiya, 152

[4] Braslavskiy I. Ya., Ishmatov Z.Sh., Polyakov V.N. (2004). Energy-saving asynchronous electric drive. Moscow, Akademiya, 256

[5] Volkov I. V., Stiazhkin S.V., Podolnyi S. V. (2009). System of stabilized current for automated electric drives. Trudih Instituta Elektrodinamiki NAN Ukrainih, 23, 64-72

[6] Kotsur M. I., Andrienko P. D., Kotsur I. M. (2012). Features of the operating modes of the modified pulse control system of an induction motor with a wound rotor. Electromechanical and energy saving systems, 3(19), 163-165

[7] Kotsur M.I., Andrienko P.D., Kotsur I. M., Bliznyakov O.V. (2017). Converter for frequencycurrent slip-power recovery scheme. Naukovyi Visnyk Natsionalnoho Hirnychoho Universytetu, 4, 49-54

[8] M. Kotsur, D. Yarymbash, I. Kotsur, Yu. Bezverkhnia (2018). Speed Synchronization Methods of the Energy-Efficient Electric Drive System for Induction Motors. IEEE: 14th International Con- ference on Advanced Trends in Radioelectronics, Telecommunications and Computer Engineering (TCSET), February 20-24, Lviv-Slavske, Ukraine, 304-307 DOI:10.1109/TCSET.2018.8336208

[9] Kotsur M. I., Andrienko P. D., Kotsur I. M. (2013)l Comparative analysis of energy efficiency of control systems for an induction motor with a wound rotor. Polzunovskiy vestnik, 4(2), 114-120

[10]Kopylov, I. P. (2001)1 Mathematical modeling of electrical machines. Moscow, Vysshaya shkola, 327

[11]Yarymbash, D., Kotsur, M., Subbotin, S., Oliinyk, A. A (2017). New Simulation Approach of the Electromagnetic Fields in Electrical Machines. IEEE: The International Conference on Information and Digital Technologies, July 5th - 7th, Zilina, Slovakia, Catalog Number CFP17CDTUSB, 452-457 DOI: 10.1109/DT.2017.8024332

[12]M. Kotsur, D. Yarymbash, S. Yarymbash, I. Kotsur (2017). A New Approach of the Induction Motor Parameters Determination in Short-Circuit Mode by 3D Electromagnetic Field Simulation. International Young Scientists Forum on Applied Physics and Engineering (YSF), October 17th 20th, Lviv, Ukraine, 207-210 DOI:10.1109/YSF.2017.8126620

[13]Chermalyih, V. M., Chermalyih A. V, Danilin A. V, Maydanskiy I. Ya. (2009). Operating modes simulation of the electromechanical systems with considering of the load type. VIsnik KDPU Imeni Mihayla Ostrogradskogo, 4 (57), 107-111

[14]Kotsur, M. I., Kotsur, I. M., Andrienko, A. A., \& Andrienko, D. S. (2016). Determination of the optimal switching frequency of the power switches of the frequency-current asynchronous-gate cascade converters. Electrical Engineering and Power Engineering, (1), 5-11. https://doi.org/10.15588/1607-6761-2016-1-1

[15]Antoshchenko N.I., Kalyuzhny V.V., Koptikov V.P., Tynda G. B., Andrienko P. D., Sadovoy A. V. (2014). A new approach to the regulation of ventilation in coal mines. Ugol Ukrainyi, 3, 29-32.

[16]. Leonharn, W (1985). Control of Electric Drives Springer. Berlin, Verlag, 123

[17]Bose, B. (1988). Power electronics and AC drive. Manchester, Englewood Cliffs, 456

The article was received 20.12 .2020

\section{ЕНЕРГОЕФЕКТИВНИЙ ЕЛЕКТРОПРИВІД ВЕНТИЛЯЦЙНИХ УСТАНОВОК}

КОЦУР І.М. канд. техн. наук, доцент, доцент кафедри електричних машин НУ "Запорізька політехніка", Запоріжжя, Україна, e-mail: igor.m.kotsur@gmail.com; ORCID: 00000001-6394-7849;

ГУРАЗДА А.В. студент кафедри електричних машин НУ "Запорізька політехніка", Запоріжжя, Україна, e-mail: artemgurazda@gmail.com; ORCID: 0000-0002-5853-2339; 
ДОЛЯ Б.О. студент кафедри електричних машин НУ "Запорізька політехніка", Запоріжжя, Україна, e-mail: bgdn.dl@gmail.com; 0000-0002-2980-9538;

ШЕСТОВ Л.С. студент кафедри електричних машин НУ "Запорізька політехніка", Запоріжжя, Україна, e-mail: luka84867@gmail.com; ORCID: 0000-0001-7255-3729.

Мета роботи. Підвищення ефективності роботи і енергетичних показників асинхронного електроприводу для стаціонарних установок вентиляторів магістралі головного провітрювання шахт.

Методи дослідження. Дослідження проводились із застосуванням методів теорії електричних кіл, математичної фізики, імітаційного моделювання, інтерполяиії та апроксимації.

Отримані результати. Проведено дослідження електромагнітних і енергетичних прочесів в системі асинхронного електроприводу з імпульсним регулюванням при вентиляторному навантаженні з урахуванням змінних аеродинамічних параметрів магістралі головного провітрювання шахт. Встановлено, щзо система електроприводу здатна з високою точністю і надійністю реагувати на зміни аеродинамічних параметрів магістралі головного провітрювання шахт, а також дозволить підвищити коефіцієнт потужності електроприводу при вентиляторному навантаженні до 0,8 $\div$ 0,93, $і$ коефіцієнта корисної дї до $(92,5 \div 94,5) \%$ при регулюванні в діапазоні робочих ковзань ротора привідного вентиляторного двигуна $s=0,5 \div s_{H}$, щзо відповідно в середньому на 0,25 і 40\% вище в порівнянні з системами нерегульованого електроприводу. Розроблено рекомендації з проектування та раціонального вибору встановленої потужності вентилятора для магістралі головного провітрювання для забезпечення найкращого рівня енергоефективності електроприводу.

Наукова новизна. Проведено дослідження електромеханічних, електроенергетичних та аеродинамічних проиесів в динамічному режимі електроприводу вентилятора. Доведено, щзо система "асинхронний двигунперетворювач" з вентиляторним навантаженням є саморегулюючою, тобто здатна реагувати з високою точністю і надійністю навіть при низьких частотах комутаиї силового ключа на будь-які зміни аеродинамічних параметрів мережі головного провітрювання шахт.

Практична чінність. Розроблено рекомендації з проектування та раціонального вибору встановленої потужності вентилятора для магістралі головного провітрювання для забезпечення найкращого рівня енергоефективності електроприводу.

Ключові слова: перетворювач, вентиляторна установка, енергоефективність, тиск, імпульсне регулювання.

\section{ЭНЕРГОЭФФЕКТИВИВНЫЙ ЭЛЕКТРОПРИВОД ВЕНТИЛЯТОРНЫХ УСТАНОВОК}

КОЦУР И. М. канд. техн. наук, доцент, доцент кафедры электрических машин НУ «Запорожская политехника», Запорожье, Украина, e-mail: igor.m.kotsur@gmail.com; ORCID: 00000001-6394-7849;

ГУРАЗДА А.В. студент кафедры электрических машин НУ «Запорожская политехника», Запорожье, Украина, e-mail:artemgurazda@gmail.com; ORCID: 0000-0002-5853-2339;

ДОЛЯ Б.А. студент кафедры электрических машин НУ «Запорожская политехника», Запорожье, Украина, e-mail bgdn.dl@gmail.com; ORCID0000-0002-2980-9538;

ШЕСТОВ Л.Е. студент кафедры электрических машин НУ «Запорожская политехника», Запорожье, Украина, e-mail: luka84867@gmail.com; ORCID: 0000-0001-7255-3729.

Цель работы. Повышение эффективности работы и энергетических показателей асинхронного электропривода для стационарных установок вентиляторов магистрали главного проветривания шахт.

Методы исследования. Исследования проводились с применением методов теории электрических ияепей, математической физики, имитациионного моделирования, интерполяции и аппроксимации.

Полученные результаты. Проведено исследование электромагнитных и энергетических процессов в системе асинхронного электропривода с импульсньм регулированием при вентиляторной нагрузке, с учетом переменных аэродинамических параметрах магистрали главного проветривания шахт. Установлено, что система электропривода способна с высокой точностью и надежностью реагировать на изменения аэродинамических параметров магистрали главного проветривания шахт, а также позволит повысить коэффиџиент мощности электропривода при вентиляторной нагрузке до 0,8-0,93, и коэффициента полезного действия до $(92,5 \div 94,5) \%$ при регулировании в диапазоне рабочих скольжений ротора приводного вентиляторного двигателя $s=0,5 \div s_{H}$, что соответственно в среднем на 0,25 и $40 \%$ выше по сравнению с системами нерегулируемого электропривода. Разработаны рекомендации по проектированию и рациональному выбору установленной мощности вентилятора для магистрали главного проветривания для 
обеспечения наилучшего уровня энергоэффективности электропривода.

Научна новизна. Проведено исследование электромеханических, электроэнергетических и аэродинамических процессов в динамическом режиме электропривода вентилятора. Доказано, что система "асинхронный двигатель-преобразователь" с вентиляторной нагрузкой является саморегулирующейся, то есть способна реагировать с высокой точностью и надежностью даже при низких частотах коммутации силового ключа на любые изменения аэродинамических параметров сети главного проветривания шахт.

Практическая ченность. Разработаны рекомендации по проектированию и рациональному выбору установленной мощности вентилятора для магистрали главного проветривания для обеспечения наилучшего уровня энергоэффективности электропривода.

Ключевые слова: преобразователь, вентиляторная установка, энергоэффективность, давление, импульсное регулирование. 